\title{
SPECIFICITY OF MORPHOFUNCTIONAL STRUCTURE OF THE HUMAN AND ANIMAL BILIARY SYSTEM (ANALYTICAL LITERATURE REVIEW)
}

DOI: 10.36740/WLek202005131

\author{
Olena B. Riabushko \\ UKRAINIAN MEDICAL STOMATOLOGICAL ACADEMY, POLTAVA, UKRAINE
}

\begin{abstract}
The aim of the paper was the study of the structure of the basic parts of the gallbladder wall of humans and animals of different classes in a comparatively anatomical aspect using the bibliographic analysis of literature sources.

Materials and methods: of the study was the contemporary publications on the anatomical and histological structure of the human and animal gallbladder wall mucosa, studied using the analysis, synthesis and summarizing of the obtained information.

Conclusions: Basically, the structure of the gallbladder wall mucosa in humans and animals of different classes has much in common; however there are also significant differences depending on the natural type of nutrition. Structural organization of the gallbladder wall in animals in comparison with humans has individual features and depends on the type of nutrition.
\end{abstract}

KEY WORDS: gallbladder, wall structure, bile ducts, types of nutrition

\section{INTRODUCTION}

Currently, the issues on the gallbladder and biliary system pathology are relevant. The most common diseases include functional disorders of the gallbladder and sphincter of Oddi, chronic cholecystitis and cholangitis, gallbladder cholesterosis, cholelithiasis, post-cholecystectomy syndrome. Cholelithiasis ranks third after cardiovascular disease and diabetes mellitus and is one of the most common human pathologies. In the economically developed countries, the number of patients increases twice every ten years. In women, this pathology occurs 3-4 times more often than in male population. There is an increase in the incidence rate with age. Publications report that the increase in the incidence of biliary system diseases is caused by the environmental factors (dietary habits, quality of food and water, type of nutrition, lifestyle) and endogenous factors. Therefore, the study of morphological features of the animal gallbladder wall, depending on the type of nutrition (herbivorous, carnivorous, omnivorous) is a topical problem, the solution of which will help in the choice of more effective treatment and methods of prevention $[1,2,3]$.

\section{THE AIM}

The study was aimed at the analysis of the structure of the basic parts of the gallbladder wall of humans and animals of different classes in a comparatively anatomical aspect depending on the type of nutrition.

\section{MATERIALS AND METHODS}

The present bibliographic analysis is based on published peer-reviewed articles, books, manuals, monographs, abstracts of dissertations. For the purposes of the systematic review, the search for literature sources (related to the study of the anatomical and histological structure of the gallbladder wall mucosa in humans and animals of different classes) was carried out using the Internet, domestic sources of scientific literature, the Scientific Library and eLibrary of the Ukrainian Medical Stomatological Academy by the key words: "gallbladder", "wall structure", "bile ducts", "types of nutrition".

The search period covered the period from 2006 to 2017, but some of the valuable data of earlier years is included in the review, as these literature sources are of considerable scientific value.

The author used the following inclusion and exclusion criteria:

- inclusion criteria: original articles published in journals and conference materials, books, manuals, monographs, abstracts of dissertations, peer-reviewed, language of publication: Ukrainian, Russian, English;

- exclusion criteria: reviews, case studies, editorials, letters, and other non-peer reviewed publications, language of publication: other.

\section{REVIEW AND DISCUSSION}

The major function of the digestive system is to enable the absorption of substances that come from the external 
environment to ensure plastic and energy metabolism. Hepatobiliary system is crucial in the processes of breakdown and digestion of organic matter. It is known that the gallbladder in the system of bile ducts performs several functions: storage and concentration of the bile, passage of bile to the duodenum, regulation of pressure in the main bile ducts, serves as a buffer reservoir of bile.

The gallbladder (vesica biliaris) is located in the gallbladder fossa on the visceral surface of the liver and adheres to the liver and leaf of peritoneum. Normally, the gallbladder sits in the longitudinal groove of the inferior surface of the liver, so that $2 / 3$ of its surface is covered by the peritoneum, and $1 / 3$ is adjacent to the liver. In relation to the peritoneum the gallbladder is located mesoperitoneally, retroperitoneally and intramurally. In some cases, it is located intraperitoneally and has a very developed mesentery that allows it to rotate at $1800^{\circ}, 3600^{\circ}, 7200^{\circ}$, and $14400^{\circ}$. The capacity of the gallbladder is usually $40-70 \mathrm{ml}$, measuring $8-14 \mathrm{~cm}$ in length and $3-5 \mathrm{~cm}$ in width. On the abdominal surface the wall thickness is from 30 to $3340 \mu \mathrm{m}$ and the wall thickness on the liver surface ranges from 230 to 1500 $\mu \mathrm{m}$. Most often the human gallbladder has a pear-shaped (63\%) and cylindrical (32\%) forms, sometimes oval, bulbous and sac-like forms (together about $5 \%$ ). The gallbladder is divided into the fundus (fundus vesicae biliaris), the body (corpus vesicae biliaris) and the neck (collum vesicae biliaris). The fundus is the widest part, facing anteriorly, that reaches the front edge of the liver, and sometimes lies behind it; the body is the middle part that lies between the fundus and the neck; the neck is the narrowed part of the gallbladder, which is directed posteriorly and tapers into cystic duct. It continuous to the liver hilum and together with the cystic duct lies in the hepatic-duodenal junction. The cystic duct has a diameter of $0.2-0.7 \mathrm{~cm}$ and a length of 1-7 cm. The angle of confluence of the cystic and common bile ducts is $22-41^{\circ}$. At a junction, where the common hepatic duct (ductus hepaticus communis) unites with the cystic duct (ductus cysticus) the common bile duct (ductus choledochus) enters into the duodenum. The common bile duct continues via the hepatic and duodenal junction to the left down and enters into the cavity of the duodenum. The length of the common bile duct is $5-8 \mathrm{~cm}$ with a diameter of 5-9 $\mathrm{mm}$, but in some pathological conditions, the choledoch can be distended up to $2-3 \mathrm{~cm}$. Publications report about the high variability of the anatomical features of topographic interposition and maldevelopment of the elements of the biliary system $[1,4,5,6]$.

It is known that the gallbladder wall is composed of three membranes: mucous (tunica mucosa), muscular (tunica muscularis) and adventitious or connective tissue (tunica adventitia). The cystic and common bile ducts have a similar wall structure. The mucous membrane forms numerous folds and crypts, the deepest of which reach the muscular membrane, forming the Rokitansky-Aschoff sinuses. The surface of the mucous membrane is formed by a layer of columnar epitheliocytes with a brush border of microvilli. The lamina propria of the mucous membrane that contains elastic fibers is underneath the covering epithelium. At the neck, the mucous membrane contains alveolar-tubular glands that secrete mucus. Less number of the above glands is found in the wall of the fundus and body of the gallbladder. The initial portions of the glands consist of glandular lobules separated by the connective tissue, and the excretory ducts are S-shaped. The mucus of the alveolar-tubular glands protects the mucous membrane from aggressive exposure to bile. The inflammatory processes of the gallbladder cause excessive mucus secretion with a high content of mucin, which leads to altered reabsorption of water and electrolytes and causes bile secretion regulation disorder. Altered physicochemical properties and biochemical structure of bile (dyscholia) are one of the factors for the formation of gallstones $[2,5,7,8]$

The covering epithelium of the mucous membrane is directly involved in the processes of reabsorption of water and several other components; consequently, bile in the gallbladder differs from bile in the hepatic ducts, having a thicker texture and a darker color. The mucous membrane of the bile ducts is formed by a layer of columnar epitheliocytes and lamina propria of the mucous membrane, made by connective tissue. Epitheliocytes contain many lysosomes and bile pigments spots. Epithelium contains small number of goblet cells, which number increases with the development of inflammatory diseases of the bile ducts. The common bile duct is lined by the mucous membrane of the common bile duct, which is formed by the simple columnar epithelium of the common bile duct and contains the glands of the common bile duct $[2,7,8]$.

The muscular layer of the gallbladder is formed by the bundles of smooth muscular fibers, run in circular direction and arranged in the form of the net. Bundles of myocytes are separated by loose connective tissue. The structure of the muscular layer is adapted to the function of the buffer reservoir of bile. When the bile passage is obstructed by the common bile duct, there is a passive increase in the capacity of the gallbladder without bile duct dilatation. The muscular tunic of the bile duct is rather thin, formed by helical bundles of smooth myocytes containing a considerable amount of connective tissue. The muscular membrane is well developed in the wall of the cystic duct when it unites with the gallbladder and in the wall of the common bile duct when it enters the duodenum. At the above sites, the bundles of the smooth myocytes form sphincter muscles. In the distal parts of the cystic duct, the sphincter of Lutkins is formed, and sphincter of Oddi is formed at the point where common bile duct enters the duodenum, regulating the processes of bile flow into the duodenum. The connective tissue layer of the gallbladder (adventitia) is formed by a dense fibrous connective tissue with numerous thick elastic fibers arranged in the form of a net. The adventitious membrane of the bile ducts is formed by a loose connective tissue $[4,7,9]$.

The gallbladder and bile ducts are innervated by the branches of the coeliac and hepatic nerve plexuses, as well as by the branching of the abdominal section of the right diaphragmatic nerve. The signal to open the sphincter muscles of the bile ducts and the secretion of bile from the 
gallbladder, as well as the secretion by mucous glands, is transmitted by parasympathetic nerve fibers. Sympathetic nerve fibers from the coeliac plexus transmit signals to keep the sphincter muscles closed, discontinue the release of bile from the gallbladder and constrict the blood vessels. Mechanical irritation of the receptors of the abdominal wall, caused by the passage of food masses, is transmitted by the fibers of the vagus nerve to the gallbladder and bile ducts. Their tone increases, but the sphincter of the common bile duct remains closed until the first portion of the food mass enters the duodenum. In this way, the reflex transfer of excitation occurs from the receptors of the abdominal wall and duodenum to the nervous apparatus of the liver and biliary tracts. The main stimuli of the process of passage of bile to the duodenum are the compounds formed by the breaking down of proteins and fats in the digestive tract.

The cystic artery supplies blood to the biliary system. It is located on the anterior surface of the cystic duct, and at the neck of the gallbladder is divided into two branches, one of which branches at the anterior edge and the other at the posterior edge of the gallbladder wall. Between the branches of the artery there is a thick net of anastomoses. In the gallbladder wall, the cystic artery creates a subserous, fibromuscular, and submucous networks of branching. The blood to the main bile ducts is supplied via the arterial branches, which create a network of anastomoses, and the blood supply to the common bile duct is via the vessels located along the duct, as well as the small branches of the right gastric artery, the artery of the fatty capsule of the right kidney, the right suprarenal artery, superior mesenteric artery. The cystic artery forms anastomoses through the system of vessels of the cystic duct with vessels of the common bile duct. The venous system of the gallbladder forms a network of anastomoses with the superior mesenteric vein, the right gastric coronary vein, the right branch of the portal vein. The mucous membrane of the gallbladder contains a dense network of small veins that form the plexus and are combined with veins of the muscular layer and with larger veins outside the muscular layer, as well as smaller veins of the subserous layer. Each main bile duct is accompanied by two veins that are combined with the gallbladder veins on the one side and the duodenal veins on the other side. The lymphatic system of the gallbladder is represented by a dense network of lymphatic vessels, which are closely related to the superficial lymphatic vessels of the liver. In the mucous membrane a deeper network of vessels lies, which joins with the superficial network of the subserous layer. The mucous membrane of the bile ducts also contains a well-branched network of lymphatic vessels, which with the help of smaller vessels joins with the lymphatic vessels of the outer membrane of the duct wall. The lymphatic vessels of the gallbladder and bile ducts drain into the cystic lymph nodes, located on the sides of the gallbladder neck $[4,5,8,10,11]$.

The lamina propria of the gallbladder mucosa contains a considerable number of lymph nodes (7-25 per percent shear area). The largest number of lymph nodes is at the gallbladder fundus, and on the path fundus continuous with the neck, their number decreases. Lymph nodes in the folds of the mucous membrane are orbicular, ovoid between the mucous and muscular layer and disk-shaped in the muscular layer $[2,7]$.

Bile from the common bile duct is the first that is discharged into the duodenum, then comes the cystic bile, and finally bile from the hepatic ducts and the liver. Contraction of the sphincter of Oddi facilitates filling of the gallbladder with bile and prevents the release of the duodenal contents into the bile ducts to avoid their infectioning. Dysfunction of the contractions of the gallbladder and sphincters of the biliary system cause dyskinesia of the gallbladder and bile ducts. Clinical manifestations of these diseases are impaired emptying of the gallbladder and other pathological conditions of the biliary system and pancreas. Publications report that diet therapy, aimed at normalizing cholesterol and fat metabolism, and stimulation of bile secretion, plays an important role in the complex treatment of biliary dyskinesia. Most often the reasons for the disorder of the bile passage to the duodenum are: gallstones, inflammatory tissue swelling, tumors, tissue fibrosis, cholangitis, parasites. Detraining of the gallbladder is caused by the lack of choleretics in consumed food, vegetarianism, imbalanced nutrition, parasitic diseases (giardiasis, fasciolosis, opisthorchiasis, ankylostomiasis) [3, 6, 11,12].

Bile (lat. bilis) is a yellow-brown or greenish biological fluid with a specific odor and a bitter taste, which is secreted by hepatocytes and accumulates in the gallbladder. Bile contains water, bile acids, bile pigments (bilirubin and biliverdin), cholesterol, lecithin, proteins, electrolytes (potassium, sodium, calcium, chlorine ions) and some other substances. Bile acids are characterized by the high surface activity, which keeps cholesterol, phospholipids and fatty acids soluble. Human bile contains mainly cholic and chenodeoxycholic acids. In mammals, bile contains mainly chenodeoxycholic, deoxycholic cholic, glycocholic and taurocholic acids. In predatory mammals, bile contains mainly tauroconjugates of cholic, deoxycholic and chenodeoxycholic acids. Porcine bile does not contain cholic acid. Bile of the freshwater fish contains cholic and chenodeoxycholic acids. However, the highest percentage of cholic acid is in the bile of predatory fish, and in benthic fish its percentage is the lowest. In the bile of most herbivorous birds, the content of chenodeoxycholic acid is predominant, while in predatory and omnivorous birds, the content of cholic acid prevails. In the intestine, bile emulsifies lipids, increasing their reaction surface for lipase hydrolysis, forms complexes with fatty acids, increases the activity of pancreatic and intestinal enzymes, facilitates absorption of fat-soluble vitamins, causing a bacteriostatic action. Cholesterol, bilirubin and some other substances are not filtered by the kidneys and their excretion occurs via bile. About $70 \%$ of bile cholesterol is excreted with feces, as well as bilirubin, steroids, glutathione, metals (copper, zinc, mercury). Bile which was formed in the liver and drained in the duodenum is called hepatic bile. In the gallbladder bile is concentrated due to reabsorption of water and other components. In this way, concentration of cholesterol, bile 
acids, bile pigments, phospholipids is increased in bile, and such bile is called cystic bile. The $\mathrm{pH}$ of hepatic bile is 7.58.0 (the reaction of the medium is slightly alkaline), and the $\mathrm{pH}$ of the cystic bile is 6.0-7.0 (acquires a weakly acidic reaction due to the formation of bile salts and absorption of hydrocarbonates). In humans and animals, the formation and excretion of bile is carried out under neurohumoral control. $[5,11,12,13,14]$.

In addition to the function of the digestive enzyme, bile plays an important role in the regulation of protein, lipid, mineral and water-salt metabolism. The enterohepatic cycle of bile acids, fat-soluble vitamins, calcium salts and other substances ensures their repeated use in metabolic cycles. Chronic bile losses cause dystrophic phenomena in the body, impaired nerve activity, incretory function of endocrine glands, metabolic processes in the bone tissue. The gallbladder accumulates primary bile acids (cholic and chenodeoxycholic), reducing their concentration in the enterohepatic circulation, which reduces the formation of secondary hydrophobic hepatotoxic bile acids (deoxycholic and lithocholic) and protects the liver, abdominal and intestinal mucosae from their aggressive impact $[9,11,13,14]$.

The digestive system of the chordates has an endodermal origin, except for the oral and posterior parts of the intestine, which are formed from the ectoderm. The evolutionary changes consisted in further differentiation and specialization of the intestinal tube, enlargement of the intestinal surface for absorption of digestive products and formation of digestive glands, both small (gastric and intestinal) and large (liver and pancreas). The liver of vertebrates is a large reticular gland that combines various functions. The shape of the liver in animals corresponds to the shape of the body and depends on the shape and location of adjacent organs. Most often the liver is divided into two lobes: right and left, which in turn can be divided into several lobes, different in size. In fish, the overall size of the liver is relatively larger than in birds and mammals. The liver of all predators is larger in size than in herbivores $[7,15,16]$.

The blood supply to the liver of animals, as well as humans, is closely related to bile formation and forms a single morphofunctional complex. The hepatic artery and the portal vein with their branches forming lobular, segmental and interlobular vessels enter the liver. In birds, the caudal aorta, at the level of the fifth and sixth thoracic vertebrae, splits into the abdominal artery and directs one of its branches to the esophagus and then splits to the right and left arteries. The left artery runs the branches to the spleen, liver, muscular and glandular stomachs, and the right artery directs the branches to the liver, gallbladder, pancreas, duodenum, jejunum, iliac and caecum. And only in predatory birds the abdominal artery splits into two independent branches of the right and left hepatic arteries, and the right hepatic artery splits into two branches to the gallbladder. From the gastrointestinal part of the digestive tract, blood to the liver is supplied by the portal vein, which branches form a capillary network. The outflow of blood is via the hepatic veins that flow into the inferior vena cava $[15,17,18]$.
In the liver, the interlobular arteries, veins and bile ducts form the hepatic triads. Publications report that, generally, histological structure of the liver of birds and mammals is very similar. Endothelial cells, macrophages and adipocytes of the liver of birds are very similar to the same mammalian cells, though in birds no natural killer cells occur among non- parenchymatous cells compared to mammals. The wall of the gallbladder is supplied with blood via the cystic artery that splits from the right hepatic artery. Venous outflow occurs through the cystic vein that flows into the right portal vein. The liver of animals contains a complex network of bile capillaries that, at the periphery of the hepatic lobules, are converted into cholangioles. Cholangioles enter the perilobular bile ducts, which extend into the interlobular ducts, which, when connected to larger bile ducts, enter the excretory hepatic ducts (ductus hepatici). The hepatic ducts join into a single duct, which forms the gallbladder. The duct from the gallbladder to the entering the first segment of the midgut is defined as a common bile duct (ductus choledochus). In some animals, hepatic ducts (ductus hepatoenterici), which enter the gut regardless of the gallbladder and common bile duct, also exists. In birds, the liver consists of two lobes that are joined together in the cranial part. The right lobe of the liver is larger and contains a gallbladder on the visceral surface. Bile from the right lobe drains into the hepatocystic duct (ductus hepatocysticus), which enters the gallbladder, and independent hepatic duct (ductus hepatoentericus) runs from the left lobe to the duodenum. The ductus cysticus and the hepatic duct of the left lobe are opened into the terminal segment of the duodenum at the level of the pylorus. In birds that do not have the gallbladder (a pigeon, ostrich, turkey, guinea fowl), the main bile ducts independently drain into the duodenum $[16,17,19,20]$.

In mammals, the division of the liver into lobules is most pronounced in pigs. The liver lobes are large, separated from each other by the taeniae of connective tissue in which vessels, nerves, bile ducts are located. In sheep, the connective tissue of the liver is much less developed and its greater part is mainly located on the border of the right and left lobes and in the area of the hepatic hilus. The liver is divided into the right and left lobes. The right lobe is larger, containing the pear-shaped gallbladder, and its edge is behind the free edge of the liver. In fish, the liver is covered by a thin connective tissue capsule, and the histological structure of the liver lobuli is expressed only by the path of the vessels and is, therefore, not clearly defined. In most fish, the histological structure of the liver is similar. The marginal zone of the liver plays the role of a fat depot, since at this site in the cytoplasm of cells there is an intense accumulation of neutral fat. In fish, the liver has a much higher percentage of fat compared to terrestrial animals $[16,21,22,23]$.

Similar to humans, the gallbladder wall of mammals, birds and fish consists of three membranes: mucous, muscular and adventitious. The mucous membrane is formed by the simple columnar epithelium and the lamina propria of the mucous membrane. The covering epithelium consists 
of light and dark brush border cells and cells that lack a brush border. The lamina propria is made of loose connective tissue. Birds and mammals have simple tubular mucous glands and lymph nodes of different size in their lamina proptia. Lymph nodes are found in herbivorous and omnivorous birds and mammals, but are absent in predators. The gallbladder mucosa of herbivorous and omnivorous mammals contains goblet cells among the epithelial cells. Thus, the mucous membrane of the gallbladder in animals is adapted to perform the resorptive and secretory functions. The mucous membrane on the inner surface of the gallbladder forms numerous folds, enlarging the area of interaction with bile and increasing the efficacy of absorption. The muscular layer of the gallbladder is made up of smooth muscle fibers that form longitudinal and circular layers. The muscular layer is well developed in omnivorous and herbivorous animals and less in predatory animals. The adventitious layer is formed by a dense connective tissue with numerous elastic fibers [19, 20, 23, 24, 25].

In animals, the wall of the extrahepatic bile ducts is also composed of three layers: mucous, muscular, connective tissue. The mucous membrane of the cystic duct, common bile and hepatic ducts forms numerous folds and is covered with simple columnar epithelium and contains the lamina propria made up of dense connective tissue. In herbivorous and carnivorous animals, the epithelium of the mucous membrane contains goblet cells, and branched mucous glands are located in the lamina propria. The mucosal epitheliocytes contain numerous lysosomes and bile pigments spots. Enhanced folding in the mucous membrane of the extrahepatic bile ducts is characteristic of animals that do not have the gallbladder. The muscular tunic consists of two layers of smooth muscle fibers: the circular inner layer and the longitudinal outer layer. Adventitia is composed of dense connective tissue. In fish, bile is excreted from the liver via intrahepatic and extrahepatic bile ducts, which are lined by simple high prismatic epithelium. No glycogen spots or granules of products of secretion are found in epithelial cells, though they form microvilli. Thus, the bile ducts are adapted not only for the outflow of bile, but also for the reabsorption of water and other substances from the primary bile into the blood. The lamina propria of the mucous membrane is formed by the longitudinal connective tissue fibers. Single smooth muscle fibers appear in the walls of the largest bile ducts. Similar to humans, the wall of the gallbladder and extrahepatic bile ducts in animals, in addition to the absorption and secretory functions, is involved in the provision of local and global immune homeostasis. Publications report that lymph nodes of the mucous membrane of birds and mammals are the dissociated analogues of bursa of Fabricius in birds. In the lymph nodes of the biliary system, B-lymphocytes acquire immune competence and immunoglobulins are synthesized [17, 19, 20, 24, 25].

Most of the vertebrates, similar to humans, have a well-developed gallbladder in which bile is stored and concentrated. It acts as a reservoir that allows the maximum amount of concentrated bile to be supplied to the duodenum during the active digestive phase, when the gut is filled with partially digested food. In all predators and many rodents, bile drains into the intestine from the gallbladder where it is concentrated both quantitatively and qualitatively (the cystic bile contains only $80-86 \%$ of water). Bile dry matter contains: bile salts (1\%), mineral salts $(0.8 \%)$, bile pigments $(0.2 \%)$, mucin $(0.3 \%)$, fatty acids $(0.14 \%)$, cholesterol and lecithin $(0.08 \%)$. In cattle and pigs the content of total lipids in bile is the highest (0.4-0.5\%), and half of them are phospholipids, which indicates the important role of bile in lipid metabolism. Most actively, lipids are absorbed in the duodenum and in the proximal segment of the jejunum. Fatty acids are insoluble in water and can only be absorbed in combination with bile acids. Moreover, bile acids increase the permeability of the intestinal epithelium for fatty acids $[13,14,18,21]$.

In fish, the structure of the extrahepatic biliary system depends on the shape of the body and the structure of the gastrointestinal tract. In herbivorous fish (a carp, grass carp, silver carp) stomach is absent, so the common bile duct enters the intestine at the beginning of the foregut. In this way, food masses contact with bile immediately after ingestion that is important, since the secretory products of the pancreas also enters together with the bile. They have a well-developed gallbladder. In a carp, it has the shape of an acorn, in a grass carp it is elongated, and in a silver carp it is orbicular. Predatory fish have a well-developed stomach, so the common bile duct enters the small intestine after gastric enlargement, and the food mass has contact with bile already at the stage of intestinal digestion $[9,14,22]$.

The gallbladder is absent in animals that consume mainly food with coarse fiber (ungulates, some rodents). Prolonged storage of bile in the gallbladder contributes to the formation of gallstones and therefore in animals, who stay long without food (camels, deer), gallbladder is absent. Due to the anatomical features of the structure of the body, very large animals (whales, elephants, rhinos) lack the gallbladder, as it should be proportional to the size of the liver. Animals that synthesize or form hydrophobic hepatotoxic bile acids are known to have a gallbladder, and in animals that synthesize hydrophilic hepatoprotective bile acids, the gallbladder is most often absent. Literature sources do not give an unequivocal answer to the question of the functional significance of the presence or absence of gallbladder in the animal world, but it is known that in animals that do not have a gallbladder, the liver has a relatively larger capacity that, apparently, compensates for the lack of the gallbladder. In animals that consume high-calorie protein-lipoid food (predators, seed rodents), the presence of the gallbladder is associated with irregular food intake. Simultaneous passage of a large amount of protein and fats to the intestine requires a large amount of concentrated bile in a short period of time. When consume low-calorie fiber, the food comes in almost constantly and contains a small amount of fats and proteins, so there is enough constant supply of low-concentrated hepatic bile. Bile is secreted by the liver constantly but with different intensity. It enters the intestine, either during digestion 
(predators), or constantly, regardless of the degree of filling of the gallbladder (cattle, pigs, rabbits). At the same time, in predators, a relatively small amount of bile is excreted with a high concentration of organic and inorganic compounds, and in herbivorous animals the release of a significant amount of less concentrated bile is characteristic. During the 24-hour period, different animals produce different amounts of bile: in pigs - 2.5-3.0 l; in sheep - $0.8-1.0 \mathrm{l}$; in dogs - 0,2-0,3 l; in chicken - 0,058 1 . In some animals that do not have a gallbladder (horses, camels, deer, rats, pigeons), its role is, to a certain extent, performed by the so-called gall tank, i.e., the enlargement of the common bile duct $[9,13,14,15,18,26]$.

The architecture of the structural components of the wall of the human gallbladder is adapted to ensure the functioning of the organ with high efficacy. The occurrence of pathology of the gallbladder and biliary system can be caused by various factors: eating habits, diet regimen, quality of food, functional state of adjacent organs, internal state of the body, environmental factors. The simultaneous effect of various factors influences the adaptive reactions of the human body.

\section{CONCLUSIONS}

Thus, the publications report that the structural organization of the gallbladder and the bile ducts of humans and animals have many similarities, but there are some differences. In humans and mammals, unlike fish and birds, mucous glands are formed in the membranes of the gallbladder wall, which are located alone or in clusters, irregularly in all areas of the wall. Moreover, fish do not have lymphoid structures in the gallbladder wall. In birds (herbivorous and omnivorous), lymph nodes are located in the mucous membrane. Mammals are characterized by an increase in lymphoid components in the gallbladder wall. The highest concentration of lymph nodes is characteristic of the gallbladder of omnivorous mammals and humans. Consequently, there was a gradual complication of the structure of gallbladder wall structures from fish to mammals with the greatest complexity reached in humans. Humans have adapted to consume a wide variety of foods, and animals of any species naturally have a more restricted diet, even if they are omnivorous animals.

\section{REFERENCES}

1. Garmatina $0 . Y$. Sovremennye metody neinvazivnoy vizualizatsii zhelchevyvodyashchikh putey [Modern methods of non-invasive visualization of the biliary tract]. Klinichna ta eksperymentaljna patologhija. 2014; 13 (2): 190-204. (Ru)

2. Ulanovska-Tsyba N.A. Osoblyvosti budovy stinky zhovchnogho mikhura u ljudyny u vikovomu aspekti [Peculiarities of the gallbladder wall in humans in the age aspect]. Svit medycyny ta biologhiji. 2014; 2 (44): 172-175. (UA)

3. Shvets $0 . V$. Funktsionalnye zabolevaniya biliarnoy sistemy: klinicheskie proyavleniya, printsipy lecheniya [Functional diseases of the biliary system: clinical manifestations, treatment principles]. Ukrajinsjkyj medychnyj chasopys. 2014; 4: 68-69. (Ru)
4. Mikhaylov S.S., Chukbar A.V., Tsybulkin A.G. et al. Anatomiya cheloveka: uchebnik [Human anatomy: textbook]. T. 2. Pod red. LL Kolesnikova. Moskva: Meditsina. 2011; 704. (Ru)

5. Dubinin S.I., Ulanovska-Tsyba N.A., Perederii N.0. et al. Morfofunkcionaljnyj stan ghepato-biliarnoji systemy v umovakh eksperymentaljnogho ghostrogho kholecystytu: monoghrafija [The morphofunctional state of the hepatobiliary system in experimental acute cholecystitis: a monograph]. Poltava. 2013; 181. (UA)

6. Kapshitar A.V. Morfologiya zhelchnogo puzyrya u bolnykh ostrym kholetsistitom, udalennogo iz minidostupa [Morphology of the gallbladder in patients with acute cholecystitis removed from the mini-access]. Patologiya. 2015; 1 (33): 95-98. (Ru)

7. Dubinin S.I., Riabushko 0.B., Ulanovska-Tsyba N.A. et al. Strukturnofunkcionaljnyj stan stinky zhovchnogho mikhura ljudyny [Structural and functional status of the gallbladder wall in human]. Svit medycyny ta biologhiji. 2016; 3 (130): 255-259. (UA)

8. Lutsik 0.D., Ivanova A.Y., Kabak K.S. et al. Ghistologhija ljudyny: pidruchnyk [Human histology: a textbook]. Kyiv: Knygha pljus. 2010; 593. (UA)

9. Riabushko 0.B. Osoblyvosti budovy zhovchnogho mikhura ljudyny i tvaryn u porivnjaljno-anatomichnomu aspekti [Features of structure of a gall bladder in human and animals in comparatively anatomical aspect]: avtoref. dys. na zdobuttja vchenogho stupenja kand. biologh. nauk: spec. 14.03.01 «normaljna anatomija». Ternopilj. 2017; 20. (UA)

10. Yang J.D., Hwang H.P., Kim J.H. et al. Duodenal window revisited: A histological study using human fetuses. Conical Anatomy. 2013; 26 (5): 598-609.

11. Seliverstov P., Skvortsova T., Teterina L. et al. Funktsionalnye rasstroystva biliarnogo trakta $i$ ikh lechenie [Functional disorders of the biliary tract and their treatment]. Vrach. 2013; 3: 9-14. (Ru)

12. Wybourn C., Kitsis R., Baker T. Laparoscopic cholecystectomy for biliary dyskinesia. Which patients have long term benefit? Surgery. 2013; 154: 761-768.

13. Lysov V.F., Ippolitova T.V., Maksimov V.I. et al. Fiziologiya i etologiya zhivotnykh [Physiology and ethology of animals]. Pod red. VI Maksimova. Moskva: KolosS. 2012; 605. (Ru)

14. Romanenko V.D. Pechen i regulyatsiya mezhutochnogo obmena (mlekopitayushchie i ryby): monografiya [Liver and regulation of interstitial metabolism (mammals and fish): monograph]. Otv. red. MF Gulyy. Kiev: Naukova dumka. 1978; 184. (Ru)

15. Romer A., Parsons T. Anatomiya pozvonochnykh [The anatomy of Vertebrates]. T. 2. Moskva: Mir. 1992; 408. (Ru)

16. Zelenevskiy N.V., Vasilev A.P., Loginova L.K. Anatomiya i fiziologiya zhivotnykh [Anatomy and physiology of animals]. Moskva: ITs Akademiya. 2009; 464. (Ru)

17. Hamodi H.M., Abed A.A., Taha A.M. Comparative Anatomical, Histological and Histochemical Study of the Liver in Three Species of Birds. Raf J Sci. 2013; 24(5):12-23.

18. Teltsov L.P., Mikhaylevskaya Ye.O., Muzyka I.G. Produktivnost i zakony razvitiya organizma zhivotnykh [Productivity and animal development laws]. Vestnik APK Verkhnevolzhya. 2011; 2: 22-27. (Ru)

19. Krasnikova L.V. Osobennosti stroeniya zhelchevydelitelnoy sistemy u kuritsy, utki i gusya [Structural features of the biliary system in chicken, duck and goose]. Sotsialno-ekonomicheskie i obshchegumanitarnye problemy Rossiyskogo obshchestva v epokhu globalizatsii: tezisy dokl. XII konf. Omskogo agrarnogo tekhnikuma. Omsk. 2015; 48-49. (Ru)

20. Riabushko 0.B. Morfologhichni osoblyvosti zhovchnogho mikhura khyzhykh ptakhiv [Morphological features of the gallbladder of predatory birds]. Svit medycyny ta biologhiji. 2015; 1 (48): 151-154. (UA) 
21. Van Ben, Donkova N.V. Makro- i mikromorfologiya pecheni ovets tuvinskoy korotkozhirnokhvostoy porody [Macro- and micromorphology of the liver of sheep of the Tuva short-fat tail]. Vestnik KrasGAU. 2015; 2: 185-189. (Ru)

22. Dekhtjarjov P.A., Jevtushenko M.Ju., Sherman I.M. Fiziologhija ryb: pidruchnyk [Fish physiology: a textbook]. Kyjiv: Aghrarna osvita. 2008; 341. (UA)

23. Gerzilov V., Petrov P. Meat Characteristics, Fatty Liver Weight and Blood Biochemical-Parameters in Force-Feeding Geese. Turkish J. of Agricultural and Nat. Sciences. 2014; 1: 802-804.

24. Riabushko O.B. Morfologhichni osoblyvosti budovy stinky zhovchnogho mikhura tvaryn zi zmishanym typom kharchuvannja [Morphological features of the structure of the wall of the gallbladder of animals with mixed type of nutrition]. Svit medycyny ta biologhiji. 2015; 4 (53): 146152. (UA)

25. Riabushko 0.B. Strukturna orghanizacija budovy stinky zhovchnogho mikhura travojidnykh tvaryn [Structural organization of the structure of the gallbladder wall of herbivorous animals]. Visnyk problem biologhiji i medycyny. 2015; 3 (120): 84-88. (UA)

26. Dubinin S.I., Riabushko 0.B., Ulanovska-Tsyba N.A. et al. Morfofunkcionaljnyj analiz budovy zhovchnogho mikhura khyzhykh ssavciv [Morphofunctional analysis of the structure of the gallbladder of predatory mammals]. Aktualjni pytannja medychnoji nauky ta praktyky. 2015; 2 (2): 388-399. (UA)
The paper has been written within the research scientific work, carried out at the Ukrainian Medical Stomatological Academy, entitled "Structural and three-dimensional organization of the exocrine glands and organs of the human digestive tract in normal condition and pathology", State registration number 0111 U 004878.

\section{ORCID and contributionship:}

Olena B. Riabushko - 0000-0003-0249-4852 A,B,D,E,F

\section{Conflict of interest:}

The Author declare no conflict of interest

\section{CORRESPONDING AUTHOR}

Olena B. Riabushko

Department of Medical Biology

Ukrainian Medical Stomatological Academy,

Shevchenko 23 str., 36011, Poltava, Ukraine

tel: +380(66)8345147

e-mail: ryabushk012@ukr.net

Received: 20.01.2020

Accepted: 27.03 .2020

A - Work concept and design, B - Data collection and analysis, C - Responsibility for statistical analysis,

D-Writing the article, $\mathbf{E}$-Critical review, $\mathbf{F}$ - Final approval of the article 